\title{
Aesthetic Moral Metaphor in The Picture of Dorian Gray and Its Influence on Modern Chinese Aesthetic Literature
}

\author{
Fang Yang ${ }^{1}$ \\ ${ }^{1}$ Department of English Education, School of Foreign Languages, Yancheng Teachers University, Yancheng, \\ Jiangsu, China \\ Correspondence: Fang Yang, Department of English Education, School of Foreign Languages, Yancheng \\ Teachers University, Yancheng, Jiangsu, China.
}

\author{
Received: March 17, 2018 Accepted: March 31, 2018 Online Published: May 14, 2018 \\ doi:10.5539/ells.v8n2p77 URL: https://doi.org/10.5539/ells.v8n2p77
}

\begin{abstract}
In "The Picture of Dorian Gray" Oscar Wilde displays his artistic pursuit on art, life and society. Although he advocates "art for art's sake", yet his works could not be isloated from the social morality. In the novel, as Dorian sells his soul to the devil for his eternal beauty in appearance, the portait burdens the change of his ugliness. In some respect, the portait is a moral metaphor of Dorian himself. Basil Hallward, the painter of the protait, can be regarded as an artist metaphor to Wilde himself. Lord Henry Wotton, a famous dandy in the novel, manifests Wilde's aestheic belief in lifestyle. So by analyzing the three main characters, this paper probes into the aesthetic moral metaphors involved in the novel, and talks about its influence on the modern Chinese aesthetic literature.
\end{abstract}

Keywords: metaphor, Oscar Wilde, Aestheticism, morality, modern Chinese Aesthetic literature

\section{Introduction}

Oscar Wilde (1854-1900) created many artistic works including fairy tales, poems, novels, dramas and literary criticism. The early 20th century witnessed the first climax of research on his productions. In China, it was fashionable to discuss Oscar Wilde and Aestheticism at that time. In the literary circle of Shanghai scholars from different literary clubs, such as Xun-mei Shao, Ke-biao Zhang, Gu Teng and Ling-feng Ye canonized Wilde's belief of "art for art's sake" and regarded Wilde as the spokesman of Aestheticism. However, they failed to understand the real value of Wilde's works and the essence of the Aestheticism. Since then, Aestheticism and Oscar Wilde have been labeled "decadent school" (Liu, 1992, p. 446) in China. It was not until 1980 when Ping Fang published "Wilde, the Happiness Prince" that the literary world in China stopped their prejudice against Aestheticism and renewed its criticism on Oscar Wilde in a more objective way.

Morality, as an abstract conception, is a basic principle for human beings to obey. It has a close relationship with politics, laws, regulations, and the arts. Metaphor is a figure of speech that refers to two things which share some common characteristics while a resemblance is compared implicitly to suggest something hidden. Metaphor does not always refer to the object directly, but is linked to something which implies some metaphorical meanings in the content. They are integrated together to express the main idea of the writer. In this respect metaphor can be regarded as a main approach to understand the implied morality in a novel. Therefore, this thesis will be focused on the study of "Dorian Gray" with the intention of revealing the moral metaphors in the novel, and discusses its influence on the modern Chinese aesthetic literature.

Oscar Wilde's works were first introduced into China in 1909. Modern Chinese writers didn't pay much attention to him until the May $4^{\text {th }}$ Movement in 1919. Furthermore in 1920s there was even a research hotspot in studying Wilde's works in China. In 1928 Mr. Shen Hong pushed out a film named "The Young Mistress's Fan" which was similar to Wilde's "Lady Windermere's Fan" in the plot-design. Another great modern scholar Mo-ruo Guo introduced Walter Pater's works into China and stated his aesthetic idea on utilitarianism of the arts. Mr. Da-fu Yu also appreciated Oscar Wilde, and presented the preface to "The Picture of Dorian Gray" to the Chinese. When Mr. Han Tian studied abroad in Japan, he read a lot of aesthetic masterpieces, such as works of Charles Pierre Baudelaire and Oscar Wilde, and then introduced them to China. Moreover, Han's translation of Wilde's drama "Salome" pushed the research in Wilde and Aestheticism to the climax in Chinese literary world in 1920s. Although so many famous Chinese modern writers was attracted by Oscar Wilde, yet Wilde's hedonistic lifestyle 
contradicted with traditional Chinese moral values. And the mainstream of Chinese modern literature could not bear its existence. In 1910s to 1940s most Chinese writers simply introduced him as the spokesman of British Aestheticism while the implied significance of his works was seldom mentioned. This paper will focus on the aesthetic moral metaphors in "The Picture of Dorian Gray" and its influence on modern Chinese aesthetic literature.

\section{Literature Review}

The Aesthetic Movement took place in France in the1830s. To advocate that art was the sole way to console life, the French writer Théophile Gautier (1811-1872) put forward his aesthetic belief of "art for art's sake" for the first time in the preface to "Albertus" (1832). Insisting on the absolute independence of art, he proposed the total neglect of literature to social life, and preached that art need not have any moral, religious, political, or educational purpose. Holding formal, aesthetic beauty as the only purpose of works of art, Gautier further systematically illustrated his aesthetic belief "art for art's sake" (Liu, 1992, p. 448) in public with the celebrated preface to "Mademoiselle de Maupin" (1835), which was regarded as the manifesto of Aestheticism for the literary world and symbolized the beginning of the French Aesthetic Movement.

At the end of the 1890s, Wilde wrote of himself as "a man who stood in symbolic relation to the art and culture of my age" (Gaunt, 1945, p. 114). As a typical aesthete, Wilde maintained that art did not reflect life, but that life imitated art. Art should not begin with the study of life, but with what was untrue and did not exist. Life and art were ultimately shaped by one's moral and spiritual nature. With passionate and elegant language, Wilde constantly returned to the theme of beauty in his works to illustrate the basic principle of his aesthetic belief, "Life imitates art, that life in fact is the mirror, and art the reality" (Bashford, 1999, p. 62).

As the master of Aestheticism, Oscar Wilde advocated his aesthetic belief on almost all the available occasions to the public, and at the same time tried every possible means to make his characters incarnations that embodied his aesthetic ideas. Although Wilde's belief in art, morality and lifestyle focused on pure art and hedonistic living, yet contradictions of his viewpoints appeared here and there in the novel. On the one hand, as a typical aesthete, Wilde could not go beyond the limitation of Aestheticism. But on the other, these contradictions actually revealed Wilde's sincere pursuit of beauty and his deep concern for art and life.

\section{The Portrait, Morality Metaphor of Dorian Gray}

"The Picture of Dorian Gray" embodies Wilde's aesthetic pondering over the relationship between art and reality. As an aesthete, Wilde spreads the aesthetic slogan "art for art's sake" (Liu, 1992, p. 448) to elaborate his aesthetic belief not only in his famous speeches and plays, but also in the novel. According to Wilde, reality imitates art while art is autonomous to everything but itself. Apart from that, he also holds that the society of his age restrains the development of human personality, limits people's desire to perceive the beauty in reality. People have vehement contradictions between body and soul, the ideal and the reality. As to art and artists, he believes that they should not be restricted by the conventional moral standards which only write off the individuality of artists. He suggests that art and artists surpass the range of conventional morality while the best achievement of artistic works is to reflect beauty. "For the artist is not concerned primarily with any theory of life but with life itself, with the joy and loveliness that should come daily on eye and ear from a beautiful external world" (Holland, 1994, p. 931). In the preface to "The Picture of Dorian Gray" Wilde puts forward that "those who find beautiful meanings in beautiful things are the cultivated. For these there is hope. They are the elect to whom beautiful things mean only beauty" (Wilde, 2014, p. 1). What Wilde really wants to say is that art and beauty are not moral or immoral, but amoral.

"The Picture of Dorian Gray" artistically tells a Gothic story about fantastic experiences of a young man, Dorian Gray, who sells his soul to the devil for eternal beauty. Upon seeing his portrait for the first time, Dorian gasps at his own beauty and laments that the picture would mock him the entire life, and complaints "I know, now, that when one loses one's good looks, whatever they may be, one loses everything...Lord Henry Wotton is perfectly right. Youth is the only thing worth having. When I find I am growing old, I shall kill myself" (Wilde, 2014, p. 24). After that, he makes the promise to sell his soul to the devil for an eternally youthful appearance. Through Dorian's voice Wilde demonstrates not only his aesthetic view on the relationship between body and soul, but also shows his emphasis on mental seeking rather than physical pleasure. In his opinion man should not only content himself with coziness of the eternal world, but also go after sensual pleasures and spiritual enjoyment. This reflects Wilde's view on "beauty sense" (Bashford, 1999, p. 43) which refers to "an identification of ourselves with the beautiful which exists in thought, action, or person, not our own" (Wilde, 2014, p. 43).

In the novel Dorian Gray's tragic fate displays Wilde's concern with the relationship between art and life, form 
and content, body and soul. The special significance that Wilde wants to convey in Dorian's experiences lies in the fact that separating his soul from the body will unavoidably lead to a tragic ending, and he should not only content himself with physical pleasure, but needs to pursue the mental enjoyment as well. About the relationship between soul and body, Wilde suggests a harmonious relationship, i.e., the body is the outer expression of the soul while the soul determines the content of the body. As Dorian separates the body from the soul, he has no choice but to endure a tragic ending.

Wilde's aesthetic viewpoints on morality are also based on his sincere pursuit of beauty, which is considered as an abstract conception quite different from beauty in reality. In this respect there are some similarities between Wilde and Plato. To Plato, beauty is speculation in philosophy. But to Wilde, beauty is a sort of perfection in the artistic world. In Plato's idealistic world, he observes beauty from the angle of morality. Whereas in Wilde's artistic works beauty is not moral or immoral but amoral. They do research in beauty in different fields, but there's something in common between them, i.e., they both differentiate beauty from conventional social conceptions and give their own unique thought over it.

In the novel, the portrait can be referred to as a metahor of Dorian Gray. The change of the picture implies the process of degeneration in Dorian. At the outset of the novel, Dorian Gray is a pure, kind-hearted young man when he is introduced to Lord Henry, "Dorian Gray is my dearest friend, and he has a simple and a beautiful nature" (Wilde, 2014, p. 16), meanwhile Lord Henry thinks that "There was something in his face that made one trust him at once. All the candour of youth was there, as well as all youth's passionate purity. One felt that he had kept himself unspotted from the world" (Wilde, 2014, p. 17). According to Oscar Wilde, "It is not merely in art that the body is the soul. In every sphere of life it is the beginning of things" (Wilde, 1994, p. 38). However, in the process of his degeneration without moral restraint, Dorian indulges himself in opium dens and bawdyhouses. He seduces Lord Henry Wotton's sister, Lady Gwendolen, and puts her in such an awkward situation that her husband and children disdain and even discard her. He tempts some young aristocrats, such as Lord Starvley, Lord Kent's only son, and the young Duke of Perth, Sir Henry Ashton. Consequently, Lord Starvley has to leave England with a tarnished name, while Sir Henry Ashton commits suicide. Most of Dorian's victims have degenerated into hell and lead miserable lives. Since Dorian has sold his soul to the devil for eternal beauty in appearance, he chooses to lead a life without the bondage of morality. Therefore, the portrait can be considered as a realistic object - a morality metaphor to illustrate his guilty soul. However, as Dorian in reality disregards the restrictions of conventional morality, his soul is separated from the body after that demonic oath, which leads to his self-destruction.

In Wilde's opinion, the attitude towards human responsibility matters a great deal to the personality. "The aim of life is self-development. To realize one's nature perfectly - that is what each of us is here for" (Wilde, 2014, p. 18). Owing to this, Dorian indulges himself in the street which is full of opium dens and prostitutes. Moreover, Wilde's respect for the development of the personality also suggests that he is an outstanding writer who concerns too much on the human beings. It also hints that his advocacy of self-development should be based on the integration of the body and soul. Because he emphasizes more on physical pleasure rather than on mental enjoyment, Dorian could not tackle with the harmonious relation between the body and soul. Therefore he could not achieve real self-development.

The self-destruction of Dorian Gray also reveals Wilde's viewpoints on morality. Seemingly, Dorian Gray's tragedy lies in Lord Henry Wotton's misguided words which force him to sink into the abyss. But actually the real reason does not come from the outer world but mainly from Dorian's selfishness and vanity. When Dorian Gray kills his friend Basil Hallward, he has become a savage and cruel murderer since he has completely lost his conscience and moral. On the night after his murder of Basil, Dorian sleeps quite peacefully without any feeling of horror or regret, "Lying on his right side, with one hand underneath his cheek, he looked like a boy who had been tired out with play, or study, the man had to touch him twice on the shoulder before he woke" (Wilde, 2014, p. 139). Having totally lost the judgment between evil and kindness, Dorian leads life numbly. In the last chapter of the novel, with the same knife that he used to kill Basil, he stabs the picture. The real intention might not be his regret for his guilty behaviors, but his intention of exterminating the picture that has witnessed his evilness. According to Oscar Wilde, "All art is immoral. For emotion for the sake of emotion is the aim of art, and emotion for the sake of action is the aim of life, and of that practical organization of life that we call society" (Holland, 1994, p. 1139). In a certain sense, the tragic fate of Dorian Gray expresses Wilde's belief in the integration of the body and the soul, which shows his deep pondering over virtue and evil.

Although Wilde preaches that art is amoral in his aesthetic theory, yet contradictions exist here and there in the novel. In the preface to the novel, Wilde acclaims that "There is no such thing as a moral or an immoral book" (Wilde, 2014, p. 1), but Dorian's degeneration actually implies a moral metaphor. Wilde himself also admits that 
"There is a terrible moral in Dorian Gray" (Winwar, 1940, p. 169), which seems contradictory to what he has said in public. However, it is reasonable for Wilde to have such paradoxical viewpoints on virtue and evil. Roditi once pointed out that Wilde had developed "a paradoxical ethics of good and evil whose Manichean identity of contraries is typical of many heresies that once flourished among the more oriental sects of Gnosticism and Early Christianity" (Roditi, 1947, pp. 65-66). In the Victorian Age, the hypocritical relationships among nobles, the cheating trade among businessmen, and the wide gap between the rich and the poor flourished everywhere. In Wilde's eyes, since no real beauty can be found in Victorian England, he has to seek for beauty in the artistic world. Therefore, to him, beauty is the archetype of an abstract perfection of idealism, and its essence is a sort of idealized existence.

Wilde's contradictions on morality also exist in his arrangement of the plot. Toward the end of the novel, Dorian in reality remains handsome while the person in the picture becomes old and ugly. The picture acts as a metaphorical image of Dorian in reality. Accordingly, it seems that art reflects the reality as art is destroyed in the ugly world. But at the end of the novel, the picture returns to its former state while Dorian dies with a withered and ugly face, which shows that beauty defeats ugly because only art, not life is pure and holy. If Dorian's desire for the "secret of life" (Wilde, 2014, p. 170) represents his seeking for physical pleasure, his portrait might be considered as a metaphor to burden his guilty soul, or as the representative of the conventional morality and ethics of his age.

\section{Basil Hallward, the Artist Metaphor to Wilde Himself}

Wilde believes that "All art is quite useless" (Wilde, 2014) and "The artist is the creator of beautiful things. To reveal art and conceal the artist is art's aim" (Wilde, 2014, p. 1). Wilde deliberately carries out the above-mentioned theory on art in "The Picture of Dorian Gray" by hiding himself behind the curtain (conceal the artist) and making his character Basil Hallward the advocate of his aesthetic view on art (reveal art). Adhering to the aesthetic doctrine of "art for art's sake" and revealing it in his artistic works, Basil Hallward, who detests vulgar realism, is a typical aesthetic artist.

The relationship between form and content is a very important part of Wilde's aesthetic viewpoints. According to Wilde, "Form is everything. It is the secret of life. Find expression for a sorrow, and it will become dear to you. Find expression for a joy, and you intensify its ecstasy... that Form, which is the birth of passion, is also the death of pain. And so, to return to the sphere of Art, it is Form that creates not merely the critical temperament, but also the aesthetic instinct, that unerring instinct that reveals to one all things under their condition of beauty" (Holland, 1994, p. 1141). As Wilde lays more emphasis on form over content. He exposes the deterioration of art and the utilitarian tendency of literature with much wit and humour. In his eye, as an accessorial instrument to form, content exists only to help the form to fulfill its function, and as its outer expression, the form determines the content.

In "The Picture of Dorian Gray", Basil Hallward, as a typical aesthetic artist, also lays his emphasis on form, not only in his artistic works, but in his daily life. As an artist, he takes "art for art's sake" as the motto of his artistic creation and regards the pursuit of beauty as the aim of art. In reality, Basil is so obsessive about Dorian's beauty that when he sees Dorian for the first time, he feels that "It would absorb my whole nature, my whole soul, my very art itself" (Wilde, 2014, p. 9). The beauty of Dorian not only suggests "an entirely new manner in art" (Wilde, 2014, p. 9), but "an entirely new mode of style" (Wilde, 2014, p. 9). Moreover, Basil is so immersed himself in seeking artistic beauty that he cares almost nothing about the evilness of Dorian. He pays attention only to the form of the beauty of Dorian, or the transient beauty at once. As to the inner world (content) of Dorian, such as the change of his inner world, he cares very, very little. Therefore, when he sees the picture which has changed completely, he was astonished, “An exclamation of horror broke from the painter's lips as he saw in the dim light the hideous face on the canvas grinning at him. There was something in its expression that filled him with disgust and loathing" (Wilde, 2014, p. 135). It is obvious that the portrait of Dorian is Basil's masterpiece which is actually to his greatest satisfaction, but the cruel reality finally destroys it completely. As Basil emphasizes too much on form by idolizing Dorian's handsome appearance, he is isolated from the cruel reality. Finally, Basil is killed by Dorian, whose vanity embedded in the soul is cultivated by Basil himself. The death of Basil Hallward has thoughtful implications: if a person separates art from reality, he will have no choice, but self-destruction. As a typical aesthetic artist, Basil lays much stress on the form of beauty, so he is doomed to have a tragic ending.

The relationship between art and reality forms another important part of Wilde's aesthetic viewpoints. According to Wilde, art does not reflect life, but life imitates art. He openly proclaims that "art never expresses anything but itself. It has an independent life, just as thought has, and develops purely on its own lines" (Holland, 1994, p. 
1091); "It is through art, and through art only, that we can revise our perfection; through art, and through art only, that we can shield ourselves from the sordid perils of actual existence" (Holland, 1994, p. 1135). In "The Picture of Dorian Gray" Basil Hallward also adheres to such a belief that life is the mirror of art. Therefore he advocates that "The sitter is merely the accident, the occasion. It is not he who is revealed by the painter; it is rather the painter who, on the coloured canvas, reveals himself. The reason I will not exhibit this picture is that I am afraid that I have shown in it the secret of my own soul" (Wilde, 2014, p. 7). According to him, the portrait is not about the sitter, but the reflection of the painter indeed. Being an aesthete, Basil puts the aesthetic slogan "art for art's sake" in practice by painting the picture of Dorian Gray and tries to create a fictitious aesthetic world, where art is pure and holy. In this respect, Basil Hallward can be regarded as an artist metaphor of Wilde himself.

In addition, Basil Hallward believes that art exceeds utilitarianism and does not relate to social reality. He does not want to sell his painting of Dorian and chooses to hide himself behind the picture, "We have lost the abstract sense of beauty. Some day I will show the world what it is; and for that reason the world shall never see my portrait of Dorian Gray" (Wilde, 2014, p. 13). Apart from that, he refuses to take part in any public parties, and detests "vulgar realism", just as he once told Lord Henry, "The harmony of soul and body-how much that is! We in our madness have separated the two, and have invented a realism that is vulgar, an ideality that is void" (Wilde, 2014, p. 12). He regards beauty in the artistic world as the unique to his artistic creation, and cares little about fame and money. Therefore, far away from the philistinism and utilitarianism, Basil Hallward is really a spokesman of Wilde's aesthetic viewpoints on art.

As a painter, Basil separates art from reality, prefers form to content, and believes that art is everything. Wilde depicts a character such as Basil to show his piety and devotion to the purity of art. Basil Hallward sublimates all his true feelings in the picture which he does not want to sell to others or show it to the public. Actually, it reveals his nature as a typical aesthete who believes that art is not utilitarian. To him, there is sense of beauty in his heart which "separates from the reason and of noble import, separates from the soul and of equal value" (Holland, 1994, p. 1146). And the sense of beauty will "lead some to create" (Holland, 1994, p. 1146). Wilde himself also confessed that "Basil Hallward is what I think I am" (Winwar, 1940, p. 135). From this perspective, we can say Basil, who is in pursuit of beauty all his life, is the incarnation of Wilde's view on art.

Although Wilde emphasizes pure art, yet contradictions really exist here and there in the novel. The tragic fate of Basil Hallward reflects Wilde's contradictory viewpoints on art as well. Basil pursues beauty not only in his artistic career but in reality. To some extent, he might be regarded as a typical aesthete who embodies Wilde's unique viewpoints on art and life. However, he is arranged to be murdered by Dorian reflecting Wilde's paradoxical viewpoints on art and life, form and content, art and reality. Believing the art does not involve reality, he lives only in an artistic world instead of a real one. He has little connection to society just as he admits that, "You know we poor artists have to show ourselves in society from time to time, just to remind the public that we are not savages" (Wilde, 2014, p. 9). And because of this, he would not be tolerated or accepted by the society. Through the characterization of Basil, Wilde preaches that art does not involve reality and it is distant from social utilitarianism. But he goes against his words and employs his pen as a weapon to challenge not only the hypocrisy of Victorian Age, but also the morality and ethics of that society. As to the relationship between art and life, Wilde maintains that art does not reflect life, but life imitates art. Art should not begin with the study of life, but with what is untrue and does not exist. However, it is inevitable that art cannot deviate from reality and life, and that art is the mirror of life. As an artist, Wilde could not live in an imagined world without ethical standards and cruel reality, and thus he could not write any works that are isolated from society.

In a word, Basil Hallward is an important character deliberately arranged by Wilde to embody his aesthetic view on art. Adhering to the aesthetic doctrine of "art for art's sake", Basil Hallward defends the purity of art, prefers form to content and devotes himself entirely to art. However, Wilde's deliberate arrangement of Basil's being murdered by Dorian Gray shows that art can never be separated from reality, and that when an artist leads a life outside of reality, he is doomed to misfortune.

\section{Lord Henry Wotton, the Metaphor to Wilde's Aesthetic View on Lifestyle}

Wilde, as the spokesman of the dandy lifestyle, tries every possible means to demonstrate his hedonistic view in public. Greatly influenced by Baudelaire and Pater, Wilde not only preaches that a flamboyant style of dress is one of the most effective means to attract attention, but also favors colourful costumes in marked contrast to the black suits of the late-Victorian middle classes in reality. Wilde liked to wear a velvet close-fitting frock with black lace decoration, velvet knee breeches with silk stockings and with a lily or a sunflower in the buttonhole to show his appreciation of beauty. Seeking for physical pleasure in experience, he liked to live extravagantly and spend money without restraint. He once admited that "I don't regret for a single moment having lived for 
pleasure... There was no pleasure I did not experience... Tired of being on the heights I deliberately went to the depths for new sensations" (Raby, 1997, p. 4). Moreover, Oscar Wilde also asserted in his writing that "Dandyism is the assertion of the absolute modernity of Beauty" (Holland, 1994, p. 1243). Therefore, as a dandy, Wilde is keenly sensitive to the value of beauty, and never wearied of dressing himself up afresh as a work of art each day.

Charles Baudelaire (1821-1867), a famous advocate of Aestheticism in France, acclaims in Le Dandy that "Dandyism is the last burst of heroism in a time of decadence" (Barnet, 1985, p. xxi). He also states that "Dandyism is like the sunset of a dying star, it is glorious, without heat and full of melancholy" (Baudelaire, 1964, p. 29). By utilizing "heroism", “decadence", "sunset", "dying", "glorious" and "melancholy", he comments impartially on dandyism. On the one hand, compared to decadence, as "the last burst of heroism", dandyism has its positive impact on the literary world. But on the other, as it belongs to the school of decadence, it is "like the sunset of a dying star", which does not much influence human beings.

In "The Picture of Dorian Gray", Wilde depicts Lord Henry Wotton as a typical dandy of the time. Lord Henry insists on a hedonistic philosophy, and forms a series of cynical theories on it as well. He once told Dorian "Live! Live the wonderful life that is in you! Let nothing be lost upon you. Be always searching for new sensations. Be afraid of nothing... A new hedonism - that is what our century wants. You might be its visible symbol" (Wilde, 2014, p. 23). According to him, "The aim of life is self-development. To realize one's nature perfectly--that is what each of us is here for" (Wilde, 2014, p. 18). With the above-mentioned attitude towards life, Lord Henry preaches the dandy's lifestyle in which new sensations are searched for and hedonism comes to be his principle of life. Apparently, his belief in the new hedonism is the true reflection of Wilde's viewpoints on lifestyle.

Lord Henry Wotton, the preacher for the hedonistic lifestyle, is a typical aesthete who talks about his aesthetic belief in public, emphasizes the self-development of one's nature, upholds the appreciation of beauty in life, and believes that "Beauty is a form of genius - is higher, indeed, than genius, as it needs no explanation. It is one of the great facts of the world, like sunlight, or spring-time, or the reflection in dark princes of those who have it" (Wilde, 2014, p. 37). Therefore, when he sees the picture of Dorian in Basil's studio, he is eager to meet the real person and wants to preach his hedonistic theory to Dorian immediately. Lord Henry always acts cynically, yet when he meets people's censure of his cynicism, he refutes them and stresses that his behavior is only to keep good virtue. In a certain sense, Lord Henry is the incarnation of Wilde himself, who tends to employ cynical speech and behavior to reveal his ironic view of the upper class in theVictorian Age.

There are many similarities between Oscar Wilde and Lord Henry Wotton. As a noble, Lord Henry lives quite a comfortable life with the new hedonism as his living motto, and regards sensual pleasure as the utmost in life, just as he admits to Dorian that "Pleasure is the only thing worth having a theory about... Pleasure is Nature's test, her sign of approval" (Wilde, 2014, p. 69); "Nothing can cure the soul but the senses, just as nothing can cure the senses but the soul" (Wilde, 2014, p. 20). Likewise, Oscar Wilde also preaches to seek for beauty all the life. "He is keenly sensitive to the value of beautiful things, and never wearies of describing to us the rooms in which he lived in, or would like to have lived" (Holland, 1994, p. 195). As Wilde seeks for new sensations and pursues a hedonistic and decadent life style, he became interested in homosexuality and received a disastrous ending to his own life. Because Lord Henry emphasized physical pleasure, he also had a tragic ending. At the end of the novel, he was an isolated and lonely old man. In addition, Wilde himself also confessed that "Lord Henry Wotton is what the world thought me: one of the new aristocracy, a dandy who lives by his wits, mocked as "Prince Paradox"" (Winwar, 1940, p. 135). According to Peter Raby, the editor of the biography of Oscar Wilde, "Oscar Wilde himself would explain the final paradox of the pose of Aesthetic dandy, he chooses, as all great dandies must, to put only his talent into his work, but his genius into his life" (Raby, 1997, p. 52). Therefore, in this respect, we can take it for granted that Lord Henry, who incarnates Oscar Wilde as a dandy, advocates Wilde's viewpoint on the aesthetic lifestyle in the novel.

\section{Influence on the Modern Chinese Literature}

When we mention the development of the modern Chinese Aesthetic literature, we should begin with The Creation Society which was founded in 1921 by students who had studied abroad in Japan. The group members included Jin-sun Tao, Fang-wu Cheng, Zi-ping Zhang, Da-fu Yu, Mo-ruo Guo, Han Tian, Bo-qi Zheng and others. Although their writing styles and creative tendency were quite different, their attitudes towards Aestheticism seemed similar. Meanwhile, the Japanese literary world at that time played an important role in the development of the Chinese Aesthetic literture from at least two aspects, i.e., intermediary and leading functions. Another litearature society, The Crescent Society was founded in 1926 when several famous Chinese scholars had a literature convention and contributed much to the development of Modern Chinese Aesthetic literature. Mr. 
Yi-duo Wen and Zhi-mo Xu were the initiators of the society while Xiang Zhu, Da-yu Sun, Meng-kan Rao, Shi-eng Yang, and Hui-yin Lin attended the convention. They discussed the Aesthetic Movement and its associated writers in western countries. They appreciated Oscar Wilde and his aesthetic statements, such as "To reveal art and conceal the artist is art's aim", and "No artist desires to prove anything. Even things that are true can be proved" (Wilde, 2014, p. 1) etc.

In modern Chinese literature Gu Teng (1901-1941) did some research in Oscar Wilde when he was studying abroad in Japan. Several of his works could be read as the imitating "The Picture of Dorian Gray". About the relationship between body and soul, Gu Teng sang high praise for man's physical pleasure. In his works, protagonists tend to sacrifice their ideal convictions and even their life for the pursuit of physical enjoyment. In his novel "The Fresco" (1922), the protagonist Tai-shi Cui has painted a piece of fresco with his own blood. In the fresco a man is sleeping while a girl is dancing on his belly. The fresco makes us think of the portrait of Dorian, which shares a tragic ending as well. In "The Fresco" physical beauty is stressed while the soul is not overlooked. In another novel, "A New Painted Idol" the protagonist Wei-qing Tan once cried, "he wants to be a modern man. He wants to achieve the hedonism, and then he would die without anything to regret" (Gu, 1927, p. 112). Obviously Gu Teng could not coordinate physical pleasure with mental pursuits, for he focused too much on the pleasure of man's body. However, although he stressed the beauty of the body, i.e. the content instead of the form of the art, yet he still showed the contradiction in his inner world by arranging tragic fates for his protagonists.

As "beauty", "love", "art", "immortality" and "death" are frequently mentioned in Wilde's aesthetic works, they integrate with each other to construct the magic artistic world. Among them, art is at the core while the others surround art in the slogan of "art for art's sake". In China, dramas are influenced by Aestheticism "the most conspicuous, though not the high-achieving one" (Zhi-xi, 2002, p. 3). In the 1920s a great number of dramatists were influenced by English Aestheticism and presented their artistic works with the themes of "beauty", "love", "art", and "death". For instance, "Zhao-jun Wang" by Mo-ruo Guo; "On the River" by Zhi Feng; "The Crazy Man" by Ye-pin Hu; and "Dream in Spring" by Wen-tian Zhang all shed light on the theme of beauty and affection among human beings. "Linli" by Wei Bai, "The Victory after Death" by Tong-zhao Wang and "A Tragedy on the Lake" by Han Tian all connect the themes of beauty, love and death. In Wei Bai's drama "Linli" the heroine Linli is a girl who believes that love is the utmost in life. She falls in love with an artist named Qinlan, but is discarded by her lover mercilessly. She could not live on without the love of Qinlan, and she eventually commits suicide to extinguish her love. This tragic story of the girl shares something in common with Sybil Van in "The Picture of Dorian Gray". This drama links love with death to elaborate on artistic beauty. In it, Lin's tragic story actually is a moral metaphor of the author Wei Bai's own experiences. The characterization of Linli actually expresses the playwright Wei Bai's aesthetic viewpoint on love and art. Before her death, Linli says, "I live only for love. Not only I myself live for love, but also my tombstone contains my crystal love. Without love is there life and art?" (Wei, 1925, p. 116) To some extent, this drama shares something common with "The Picture of Dorian Gray", which also hides a moral methor. In Du-qing Wang's poem "Venice", he expresses his expectation for the coming of death. In another famous poet Jin-fa Li's poems, death is not horrible, but the echo of the mind and an escape for the poet himself. In the1920s, in the modern Chinses literature, death is also immortal to show its aesthetic appeal to readers.

\section{Conclusion}

Wilde's originality lies in his making his characters the incarnations of his aesthetic viewpoints on morality, art and lifestyle. In the novel Dorian Gray, the main character is the spokesman for Wilde's aesthetic view of morality. Basil Hallward, the painter of the portrait, is the advocate for Wilde's aesthetic views on art. Lord Henry Wotton, typical of the dandies of the time, is the preacher of Wilde's aesthetic views on lifestyle. The portrait, which acts as the moral metaphor of Dorian Gray, carries Wilde's aesthetic views on art, lifestyle and society. Basil Hallward, the painter of the portrait, is the artist metaphor for Wilde himself. Lord Henry Wotton can be regarded as a metaphor of Wilde's Aesthetic view on lifestyle. The self-destruction of Dorian Gray, the death of Basil Hallward and the sad solitary condition of Henry Wotton are Wilde's deliberate arrangements of the ending of the characters, which symbolizes the fate of Victorian intellectuals. Through these metaphors, Wilde conveys to his readers that if an intellectual fails to be a man of morals, fails to reach the integration of the body and the soul or fails to enjoy life in an artistic way, he is doomed to have a tragic ending like the characters in his novel.

\section{Acknowledgements}

This work is supported by Top-notch Academic Programs Project of Jiangsu Higher Education Institutions 
(No. PPZY2015A012)

\section{References}

Barnet, S. (1985). Introduction. The Importance of Being Earnest and Other Plays by Oscar Wilde. London: Penguin Books.

Bashford, B. (1999). Oscar Wilde The Critic as Humanist. London: Associated University Presses.

Baudelaire, C. (1964). "The Painter of Modern Life." The Painter of Modern Life and Other Essays. trans. and ed. Jonathan Mayne. New York: Da Capo Press.

Gaunt, W. (1945). The Aesthetic Adventure. London: Jonathan Cape.

Gu, T. (1927). The Aesthetic Literature. Shanghai: Guanghua Book Bureau.

Holland, M. (1994). Complete Works of Oscar Wilde. London: Harper Collins Publisher.

Liu, B. (1992). A Short History of English Literature. Zhenzhou: Henan People's Publishing House.

Raby, P. (1997). The Cambridge Companion to Oscar Wilde. London: Cambridge University Press.

Roditi, E. (1947). Oscar Wilde. Norfolk, CT: New Directions Books.

Wei, B. (1925). Linli. Beijing: The Commercial Press.

Wilde, O. (1994). Complete Works of Oscar Wilde. Glasgow: HarperCollins Publishers.

Wilde, O. (2014). The Picture of Dorian Gray. Nanjing: Yilin Press.

Winwar, F. (1940). Oscar Wilde and the Yellow' Nineties. New York: Harper \& Brothers Publishers.

Zhi-Xi, J. (2002). Youth, the Devil. Beijing: Tsinghua University Press.

\section{Copyrights}

Copyright for this article is retained by the author(s), with first publication rights granted to the journal.

This is an open-access article distributed under the terms and conditions of the Creative Commons Attribution license (http://creativecommons.org/licenses/by/4.0/). 